\title{
A NOTE ON THE LEGAL STATUS OF SHARE- TENANTS AND SHARE-CROPPERS IN THE SOUTH
}

\author{
A. B. Book ${ }^{*}$
}

The plight of the share-tenant and share-cropper has received attention from many sources in recent years and the terms have appeared often in the press, in literary publications, and in governmental regulations and documents. That the South possessed a social and economic share-cropping problem was well known to students of that area for many years, yet it required the impact of a world-wide depression and the resultant efforts of the New Deal, which became so uncomfortably involved in the problem through the operations of the Agricultural Adjustment Administration, ${ }^{1}$ to bring to it some measure of public recognition. With all this, however, there has been no full treatment of the legal status of the share-tenant and share-cropper published. ${ }^{2}$ The number of relevant cases and statutes is large, and this note can do no more than indicate their salient features.

Share-tenancy, that is the renting of lands for agricultural purposes with a share of the crop as the specified rent, exists throughout the United States. The cropper system, by which is meant the share cultivation of land under a contract by which the landowner retains control of the land and supplies all except the labor, prevails principally in the southern cotton and tobacco areas. This system had its origin in the adjustments made necessary by the abolition of slavery, particularly in the fact that the freed slave had neither the financial resources nor the education in selfreliance to enable him to earn an independent livelihood. Once established, the system continued of its own momentum and that of the system of excess charges for credit which immediately became a part of it and operated to deprive the cropper of from twenty to thirty percent of his share of the crop.

- A.B., r930, Duke University; r930-1932, George Washington University Law School; LI.B., I934, Duke University School of Law. Member of the North Carolina Bar. Legal assistant to Professor Paul W. Bruton, then of the Duke University Law School Faculty, while the latter was engaged in the handling of landlord and tenant benefit claims disputes for the Agricultural Adjustment Administration in 1934 .

${ }^{1}$ Bruton, Cotton Acreage Reduction and the Tenant Farmer, (June 1934) I Law and Contemporary Problems, 275.

agricultural Bibliography No. 7o, Farm Tenancy in the United States, 19r8-1936, published by the Bureau of Agricultural Economics, United States Department of Agriculture, contains one reference on the legal status of the share-cropper. This reference is to typewritten memoranda on the agricultural landlordtenant problem in Alabama, Arkansas, Georgia, Mississippi, North Carolina, South Carolina, Tennessee, and Texas prepared by the Agricultural Adjustment Administration in 1934, and made the basis of this paper. 
The South's most important agricultural contract is the crop-share agreement by which the land of one person is cultivated by another on a share-of-the-crop basis. Under such contracts, the majority of them oral, some $1,500,000^{3}$ share-tenants and share-croppers live and work, the agreement sometimes providing that the cropper not drink intoxicating liquors, use profane language or allow any idleness or loafing around the premises. ${ }^{4}$ While there are any number of varieties of crop-share agreements, some of which are a combination of the crop-share agreement with a cash or fixed rent provision in regard to pasture land and land to be cultivated in a commodity other than the principal one, they are of two major types. ${ }^{5}$ In accordance with one the landowner furnishes only the real estate, the operator furnishing the work-stock, equipment, seed and fertilizer, generally receiving one-fourth of the cotton crop and one-third of the grain crop produced. Such a tenant or cropper operating under this type of contract is often referred to as a fourth "renter" or as a third and fourth "renter." However, the use of the term "renter" is misleading because the cultivator may or may not be a renter or tenant in the technical sense, depending upon considerations which will be discussed later.

The other principal type of crop-share agreement is that under which the landowner supplies the work-stock and equipment, and possibly half of the seed and fertilizer, in addition to the land. This leaves to the operator the responsibility only for furnishing the labor and part, if not all, of the fertilizer and seed, the latter being "advanced" to the cultivator by the land-owner, to be paid for when the crop is harvested. Under these conditions the crop is divided between the parties on a fifty-fifty basis. This type of contract is usually held to have created a cropper relationship, but may be "interpreted," depending upon factors dealt with in succeeding paragraphs, as giving rise to a tenancy.

In examining into the tests by which it is determined whether a particular cropshare agreement created a tenancy or a cropper relationship, it must be remembered that, there being no standard form of either the share-rental or the share-cropping agreement, the ruling in a given case may have been influenced by provisions of the agreement not evidenced in the opinion and from which it might have been found that the parties "intended" one of the possibilities to the exclusion of the other. ${ }^{0}$ It has been said that while no particular words are necessary to create the relation of landlord and tenant, it is indispensable that it should appear to have been the inten-

\footnotetext{
- The Census enumeration does not distinguish between the cash-, fixed-rent-, or share-tenant. The 1935 Census of Agriculture indicates that in 16 southern states there are $1,115,219$ tenants and 716,256 croppers.

"Such were the additional restrictions in the agreement considered in State v. Sanders, Iro S. C. 487 , 96 S. E. 622 (1918).

${ }^{5}$ For a further analysis of the usual provisions of such contracts, see Vance, Human Factors in the South's Agricultural Readjustment (June, 1934) I Law and Contemporary Problems, 259, 267.

${ }^{6}$ It is also possible in any case where the evidence of intent is not clear that the court may be influenced to place the transaction in one category or the other by a consideration of the results which will follow from its characterization of the transaction. In other words, what appears to be a preliminary to the decision of the specific issue before the court may in fact be only the consequence of a decision reached on other grounds not articulated in the opinion. This phenomenon is not unusual in the judicial process.
} 
tion of one party to dispossess himself of the premises and of the other to occupy them. ${ }^{7}$ Where the cultivator furnishes only the labor, apparently since the landowner has risked the safety and well-being of his equipment and work-stock, the courts have felt that there is a presumption that the parties intended a croppingrelationship. Where the landowner furnishes only the land, however, the contrary presumption does not arise and the courts have said that the intent of the parties is to be found in whether the agreement provides that the landowner receives his share "from" the cultivator or vice versa, that "rent" is to be paid, or that the cultivator is subject to supervision by the landowner.

The crop-share cultivator who is considered a tenant proper has a legal estate in the land rented and the title to and possession of the crops grown. ${ }^{9}$ The cropper, on the other hand, is generally held to have no estate in the land but only a right of ingress and egress for the purpose of cultivation, the crop belonging either to the parties as tenants in common or to the landowner alone. These basic differences between the rights of the share-tenant and share-cropper in the land they cultivate and the crops they produce, do not, however, make a great difference as between the parties themselves, except in the method and ease of enforcement of the landowner's claim, because the landowner has, by statute, been given a lien for the tenant's rent and for money and supplies advanced to the tenant or cropper during the year. In both situations there has been a tendency, by statute and judicial interpretation, to increase the security of the landowner at the expense of the share cultivator, treating the latter as of a class which would default in its obligations if the slightest opportunity existed.

Each of the southern states has enacted legislation giving the landlord a lien upon the crops produced as security for the rent and for money and supplies furnished to the tenant to make the crop. ${ }^{10}$ Not only are the landlords who make advances to tenants protected by a statutory lien, but in North and South Carolina a similar lien, superior to all liens except the landlord's lien for rent and the laborer's lien for his services, has been given to all others who make advances for agricultural purposes. ${ }^{11}$

Various criminal provisions are also in force intended to regulate the landlordtenant relationship. Many of these apply to the cropper situation as well. Thus, it

'Brown v. Johnson, I88 Tex. 143, I2 S. W. (2d) 543 (1929).

${ }^{8}$ Barnhardi v. State, 169 Ark. 567, 275 S. W. 909 (1925).

'Cry v. Bass Hardware Co., 273 S. W. 347 ('Tex. Civ. App. 1925): Schlicht v. Callicott, 76 Miss. 487, 24 So. 869 (1899); Alexander v. Zeigler, 84 Miss. 560, 36 So. 536 (1904); Hardeman v. Arthurs, I 44 Ark. 289, 222 S. W. 20 (I920); Barnhardt v. State, I69 Ark. 567, 275 S. W. 909 (rg25); SchoenlauSteiner Trunk Co. v. Hilderbrand, 152 Tenn. 166, 274 S. W. 544 (1925); Taylor v. Coney, ror Ga. 655, 28 S. E. 974 (1897); Fields v. Argo, 103 Ga. 387 , 30 S. E. 29 (1898); Souter v. Cravy, 29 Ga. App. 557, II6 S. E. 231 (1923); Brock v. Haley \& Co., 88 S. C. 373,70 S. E. I011 (1911).

${ }^{10}$ ARK. Dig. Strat. (Crawford \& Moses, 1921) \$\$6889, 689o; Ala. Code (Michie, 1928) $\$ 8872,8873$; GA. Code (1926) \$\$3340, 3348; Miss. CODE (1930) \$\$2186, 2187, 2188; N. C. CoDE (Michic, I935) \$2355; S. C. Code (I932) \$8771; Tenn. Code (Williams, Shannon \& Harsh, r932) \$\$8017-I9; TEx. CoMp. StAT. (1928) art. 5222.

${ }^{4}$ N. C. CODE (Michie, 1935) \$2480; S. C. CODE (1932) §8779. 
is a misdemeanor to dispose of or to conceal any part of a crop subject to a landlord's lien, provided, of course, that it is found that there existed an intent to deprive the lienor of his security. ${ }^{12}$ It is further made a misdemeanor to entice away or knowingly employ a tenant or cropper or to otherwise interfere with the tenant or cropper relationship prior to the expiration of the term, ${ }^{13}$ or to buy or sell cotton between the hours from sunset to sunrise. ${ }^{14}$ And in North Carolina it is made a misdemeanor to buy or sell seed cotton in a quantity less than that which is usually baled, unless the purchaser keeps complete records, open to public inspection, of such transactions. ${ }^{15}$ The purpose of all these provisions, of course, is to make it difficult for tenants and croppers to defraud the landlord of their share of the crop.

Alabama and North Carolina have, by statutory enactment, abandoned the legal distinction between share-tenants and share-croppers. The method used by these states differs materially. In Alabama the statute provides that where one party furnishes the land and the other the labor to cultivate it, the crop to be divided, the relation of landlord and tenant with all its incidents shall be held to exist regardless of which of the parties furnishes the teams, feed, and fertilizer. ${ }^{16}$ The statute has apparently not affected their economic and social status, and it may be noted that the Agricultural Census of 1935 nevertheless indicates that there are 77,974 croppers in Alabama.

In North Carolina, under the statute of $1876-77$, the cropper and tenant occupy the same position as far as ownership of the crop is concerned. While the statute lessened the tenant's rights in the crop by increasing the landlord's rights as a lienholder, ${ }^{17}$ it at the same time raised the cropper's status from that of a laborer receiving pay in a share of the crop with title to the crop vested in the landowner, to that of one having a right to actual possession subject to the landowner's lien. ${ }^{18}$ The statute declares that any crops raised by a tenant or cropper are vested in possession of the landlord until the rents and advancements are paid and that "this lien shall

${ }^{23}$ ARK. DiG.-STAT. $\$ \$ 2552,2553$ (the latter section deals with those aiding and abetting); GA. ConE \$729; Miss. CODE \$\$10I8-1020; N. C. CODE \$4288; S. C. CODE \$1276; TENN. CODE \$8025, II265-11266; Tex. Comp. Stat. art. 5225, 5226.

is ARk. Dic. Stat. $\$ 2789$, (penalty of a fine from $\$ 25$ to $\$ 100$ and liability to landowner for advances he made and damages sustained); GA. CODE $\$ \$ 123-25,37 J 2 ;$ MISs. CODE $\$ 900$.

14 Ark. Dig. Stat. \$2439; Ga. Code \$555; Miss. Code \$838; N. C. Code $\$ 4467$; S. C. Code \$6391; TEN.v. CODE $\$ \$ 11260-63$.

${ }^{15}$ N. C. CODE (Michie, 193I) $\$ 5083$.

${ }^{16}$ Ala. CODE (Michie, 1928) $\$ 8807$ : "When one party furnishes the land and the other party furnishes the labor to cultivate it, with stipulation, express or implied, to divide the crop between them in certain proportions, the relation of landlord and tenant, with all its incidents, and to all intents and purposes, shall be held to exist between them; and the portion of the crop to which the party funishing the land is entitled shall be held and treated as the rent of the land; and this shall be-true whether or not by express agreement.or by implication the party furnishing the land is to furnish all or a portion of the teams to cultivate it, all or a portion of the feed for the teams, all or a portion of the planting seed, all or a portion of the fertilizer to be used on the crop, or pay for putting in marketable condition his proportion of the crop after the same has been harvested by the tenant."

${ }^{17}$ See Howland v. Forlaw, 108 N. C. 567,13 S. E. 173 (1891), and cases cited as to rights of tenants prior to the statute.

${ }^{13}$ Sce State v. Austin, I23 N. C. 749 , 3r S. E. 731 (I898) as to status of cropper prior to the statute. 
be preferred to all other liens." 19 It is to be noted that the statute applies only where it is not otherwise agreed between the parties. No case has reached the appellate court where an agreement providing for a lien contrary to that in the statute was a point at issue.

In interpreting the statute the North Carolina Supreme Court has, correctly it would seem, treated the statute as one primarily and solely designed to secure the landowner in his rent and advances and has held that he is a "trustee in (constructive) possession" until the debts are paid and that he acquired no title to the tenant's share. ${ }^{20}$ In so doing the court has pointed out that while the first section vests possession of the crop in the landlord, the second section recognizes the actual possession in the lessee or cropper until the division or surrender of the crop to the landowner. 21

Where the distinction between share-tenant and cropper has not been so affected by statute, the cropper is said to be an employee, the crops belonging either to the cropper and landowner as tenants in common or to the landowner alone, subject to the cropper's lien as a laborer for his share after division and deduction for advances made to him during the year. The holding that the parties to a cropping agreement are tenants in common appears well established in Texas, Tennessee, and Mississippi. $^{22}$ The cropper can therefore maintain an action for partition of the crop, can recover for conversion, can interplead for his share of the cotton grown and may mortgage or sell his share of the crop which his labor produced. ${ }^{23}$ Where the cropper brings action for conversion of a crop which he was unable to complete because of a wrongful ejectment, the value of his share, without deduction of the cost of harvesting and selling, may be recovered. ${ }^{24}$ If the action be one for breach of contract, as where the landowner failed to furnish sufficient money with which to

${ }^{20}$ N. C. CODE (Michie, I93I) \$2355, provides that: “When lands are rented or leased by agreement, written or oral, for agricultural purposes, or are cultivated by a cropper, unless otherwise agreed between the parties to the lease or agreement, any and all crops raised on said lands shall be deemed and held to be vested in possession of the lessor or his assigns at all times, until the rents for said lands are paid and until all the stipulations contained in the lease or agreement are performed, or damages in lieu thereof paid to the lessor or his assigns, and until said party or his assigns is paid for all advancements made and expenses incurred in making and saving said crops. A landlord to entitle himself to the benefit of the lien herein provided for, must conform as to the prices charged for the advance to the provisions of the article Agricultural Liens, in the chapter Lieris.

"This lien shall be preferred to all other liens, and the lessor or his assigns is entitled, against the lessee or cropper, or the assigns of either, who removes the crop or any part thereof from the lands without the consent of the lessor or his assigns, or against any other person who may get possession of said crop or any part thereof, to the remedies given in an action upon a claim for the delivery of personal property. ..."

${ }^{90}$ Cf. Batts v. Sullivan, 182 N. C. 129,108 S. E. 511 (I921) where it was said that "possession and title" to all crops are deemed to be vested in the landlord.

${ }^{21}$ State v. Copeland, 86 N. C. $69 \mathrm{~g}$ (1882); Tobacco Growers Ass'n v. Bissett, 187 N. C. 180, 12I S. E. 446 (rg24).

Tignor v. Toney, ${ }_{3}$ Tex. Civ. App. 518, 35 S. W. 88I (1896); Doty v. Heth, 52 Miss. 530 (I876); Staple Cotton Co-op. Ass'n v. Hemphill, 142 Miss. 298, 107 So. 24 (1926); Mann v. Taylor, Executrix, 52 Tenn. 267 (1871); Hunt v. Wing, 57 Tenn. 139 (1872).

${ }^{2}$ Fagan v. Vogt, 36 Tex. Civ. App. 528, 8o S. W. 664 (1904); Barnett v. Govan, 241 S. W. 276 (Tex. Civ. App., I922); Hunt v. Wing, 57 Tenn. 139 (1872); Jones v. Chamberlin, 52 Tenn, 211 (1871).

as Fagan v. Vogt, supra note 23. 
make the crop, the measure of damages is the value of the share less necessary expenditures, not including labor, and less such sums as the cropper may have earned in other employment. ${ }^{25}$

In Texas it has been held that the statutory lien given a landlord for rent, money and the value of equipment furnished does not apply where the relationship of landowner and cropper is established. While it was indicated in two cases ${ }^{20}$ that this followed because the parties were tenants in common of the crop produced, consideration must be given to the fact that the statute applies to persons "renting or leasing" lands and refers to the lien as being upon the property of the "tenant." The statute also grants a lien for money and supplies advanced in those cases where the landowner furnishes everything except the labor and the "tenant" furnishes the labor. ${ }^{27}$ In the only cases decided under this provision the cultivator was a "third and fourth renter" and had given a note acknowledging the existence of a lien to secure the payment. ${ }^{28}$

The Mississippi statute providing for a landlord's lien on the crops produced by his tenant is similar to that of Texas. Special protection is granted to the tenant, however, where distress or seizure and sale is made where no rent or sum for supplies is due, in the provision that the tenant may in such case recover double the value of the property taken. ${ }^{29}$ Although no case has been found on the point, it would seem that the statute applies only where the relationship is that of landlord and tenant. Another section of the statute does, however, specifically give the landowner a lien on the cropper's share of the crop for the money and "fair market value" of other things advanced by him or by another at his request, and grants a corresponding lien for wages on the interest of the employer in favor of "every employee, laborer, cropper, part owner, overseer or manager or other person" who aids in the cultivation or harvesting of any crop. ${ }^{30}$ The landowners' statutory lien for supplies has been passed upon in one case, ${ }^{31}$ but no cases were found in which the cropper's or part owner's lien was being asserted.

Tennessee statutes also give the landlord a lien for rent on all crops grown on the land and a lien for money, supplies, equipment advanced to or used by his tenant or share-cropper. It is further provided that it is the intention of the statute to treat the portion of the crop "reserved as rent by the landlord of a share-cropper" as vested in the landlord, unless the contract expressly provides otherwise. ${ }^{32}$ The sharecropper also has a lien on the product of his labor under a section of the code which has not been reviewed by the appellate court. ${ }^{33}$

The rule that the share-cropper is an employee with no title to the crop until

\footnotetext{
\$ Matthews v. Foster, $238 \mathrm{~S}$. W. 317 (Tex. Civ. App. 1922).

${ }^{23}$ Rosser v. Cole, 226 S. W. 510 (Tex. Civ. App., 1921); Brown v. Johnson, supra note 7.

${ }^{27}$ TEX. CoMp. Stat. (I928) art. 5222.

${ }^{23}$ Spurlock v. Hilburn, 32 S. W. (2d) 396 (Tex. Civ. App. 1930).

* Miss. Code (1930) \$2218.

supra note $29, \$ 2238$.

22 Tenn. CODE (1932) 58027 .

at Betts v. Ratliff, so Miss. 561 (1874).
${ }^{*}$ Supra note $32,58014-16$.
} 
after there has been actual division and the landowner has received his share and full payment for advances is followed in Arkansas, ${ }^{34}$ South Carolina and Georgia. ${ }^{35}$ In the latter state statutory enactment defines a cropper as one employed to work part of a crop and specifically provides that the title to and right to control and possess the crop grown is vested in the landowner until he has received his share and is fully paid for all advances made to the cropper during that year. ${ }^{38}$ It was therefore held that a cropper is guilty of larceny who disposes of the crop raised before settlement has been had with landowner. ${ }^{37}$

The cropper does, however, have some interest in the crop prior to its division. He may, for example, mortgage his interest in the crop, but such a mortgage may not be foreclosed until the cropper's interest has ripened into a title by the satisfaction of the debt owed to the landowner. ${ }^{38}$ As against the interest of the landowner, therefore, the cropper's interest is quite clearly secondary, although the cropper does have, as a laborer, a statutory lien on the crops which his labor produces, ${ }^{30}$ and before being permitted to foreclose his lien the cropper must show full performance of his contract or that such performance was rendered impossible by the unauthorized acts and conduct of the landowner. ${ }^{40}$ Where the cropper attempts to assert his rights as against the landowner he is further impeded by the system of advances on credit. Since usually the landowner alone keeps a record of advances, he could easily show, if his intent were fraudulent, that the cropper had no equity in the crop over the former's share and payment for the supplies advanced to the latter. This situation is probably corrected very little by such legislation as exists in South Carolina, under which the cropper may insist upon a division of the crop by a disinterested person chosen by the parties or selected by the nearest magistrate.41

In several cases the Arkansas court has held the landowner and cropper to be tenants in common in the crop, but it is doubtful that this can be called the general rule. In several of the cases holding that the landowner had title, he had retained title to the crop by the terms of the contract. Ponder v. Rhea, 32 Ark. 435 (1877); Sentell v. Moore, 34 Ark. 687 (1879); Valentine v. Edwards, Ir2 Ark. 354, I66 S. W. 531 (1914). In Tinsley v. Craige, 54 Ark. 346, I5 S. W. 897 (189r), the court, while holding that the landowner and cropper in the case before it were tenants in common, laid down the general rule that the landowner had title to the crop of his share-cropper, stating that "In former decisions of this court, where stress has been laid on the fact that the land-owner and occupant were tenants in common of the crop, it was to distinguish their title to or interest in the crop from the ordinary incidents of ownership that exist as between landlord and tenant and land-owner and cropper, in order to determine the remedies of the parties in suits about the crop, or to ascertain their respective interests in it, and not for the purpose of determining their relation to each other."

${ }^{36}$ People's Bank v. Walker, 132 S. C. 254, r28 S. E. 715 (x925), and cases there cited; Fountain v. Fountain, 10 Ga. App. 758, 73 S. E. 1096 (19r2); Souter v. Cravy, II6 S. E. 231 (Ga. App. 1923), in which the court said: "It is possible, however, for a contract of landlord and tenant to be entered upon whereby the person renting and taking over the land is to pay therefor a certain fixed proportion of the crops. ..."

${ }^{a 7}$ State v. Sanders, rio S. C. 487,96 S. E. 622 (1918).

${ }^{39}$ Fountain v. Fountain, ro Ga. App. 758, 73 S. E. Iog6 (I9I2); Parkes v. Webb, 48 Ark. 293, 3 S. W. 521 (1887); Malcolm Mercantile Co. v. Britt, I02 S. C. 499,87 S. E. I43 (1915); Miller v. Ins. Co., 146 S. C. 123,143 S. E. 663 (1928).

${ }^{\infty} \$ 3335$, Ga. Code (Ig26); $\$ 8772$, S. C. Code (I932); $\$ 6848$, ARK. Dig. Stat. (I92I). See also McElmurray v. Turner, 86 Ga. 215, I2 S. E. 359 (I890); Howard v. Franklin, 124 S. E. 554 (Ga. App. 192.4); Birt v. Greene \& Co., 127 S. C. 70, 120 S. E. 747 (1924); Burgie v. Davis, 34 Ark. I79 (I879).

${ }^{\circ}$ Payne v. Trammell, 29 Ga. App. 475 , 155 S. E. 923 (1923).

4S. C. CODE (1932) §7031. 